\title{
Suppression of PinX1 resulted in telomere dysfunction and enhanced radiosensitivity in osteosarcoma cell lines
}

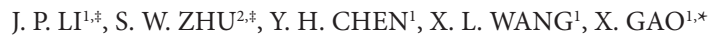 \\ ${ }^{1}$ Department of orthopedics, Tianjin No.5 Central Hospital, Tianjin 300450, China; ${ }^{2}$ Department of orthopedics, Tianjin Hospital, Tianjin \\ 300211, China \\ ${ }^{*}$ Correspondence: gaox300@126.com \\ ${ }^{*}$ Contributed equally to this work.
}

Received February 8, 2015 / Accepted July 13, 2015

\begin{abstract}
Telomeres have emerged as a promising and important factor modulating cellular and organism responses to ionizing radiation (IR). Pin2/TRF1 interacting protein X1 (PinX1) is an intrinsic telomerase inhibitor and a putative tumor suppressor gene in human cancers. The aim of this study is to investigate the role PinX1 in osteosarcoma (OS) radioresistance. A telomerase-positive OS cell line Saos-2 and a telomerase-negative OS cell line U2OS were used. PinX1 shRNA lentiviral vetors were constructed and transfected to cells. PinX1 expression was determined by real-time quantitative PCR (qPCR) and Western blotting. Relative telomere length (RTL) was detected by using qPCR. Flow cytometric analysis was used to detect cell cycle and apoptosis. Radiosensitivity was determined by colony formation assay. Data showed that, PinX1 knockdown resulted in telomere shortening, $\mathrm{G}_{1}$ phase arrest, increased apoptosis and enhanced IR sensitivity both in Saos-2 and U2OS cell lines, regardless of telomerase status. Our study concluded that PinX1 could serve as a novel predictor for radiotherapy response to OS patients, and the pathway of PinX1-mediated telomere stability might represent a new target to improve the radiotherapy effect of OS.
\end{abstract}

Key words: PinX1, telomere, radiosensitivity, osteosarcoma

Osteosarcoma (OS) is the most common primary solid bone tumor in adolescents. Despite the combination of neoadjuvant chemotherapy and radical surgery, a 5 -year survival rate is not improved as a result of local recurrence and metastases [1]. Ionizing radiation is one of the most effective approaches for local control, and the benefits of preoperative radiotherapy in OS include reducing tumor viability before surgery, increasing the probability of performing limbsparing surgery, and decreasing the risk of local recurrence [2]. However, many OS patients present the characteristic of radioresistance, consequently preventing successful treatment $[3,4]$. Therefore, the molecular mechanism of radiotherapy resistance in OS should be focused on.

Recently, telomeres have emerged as a promising and important factor modulating cellular and organism responses to ionizing radiation (IR). Many studies have shown that telomere shortening and dysfunction impair DNA repair and significantly modulates the effects of IR [5,6]. Pin2/TRF1 interacting protein $\mathrm{X} 1$ (PinX1) is a newly cloned gene mapped to chromosome $8 \mathrm{p} 23.1$, a region frequently associated with loss of heterozygosity (LOH) in cancer [7]. Previous studies have identified PinX1 as a critical component in regulating telomerase activity both in vitro and in vivo. Overexpression of PinX1 in tumor cells could inhibit telomerase activity, shorten telomeres, and suppress tumor growth, whereas depletion of endogenous PinX1 has the opposite effects [8,9]. However, the molecular status of the PinX1 gene and its expression patterns showed contradictory between different types of tissues and tumors [10-12], suggesting that the abnormalities and/or functions of PinX1 in tumorigenesis are complicated and may be tumor-type-specific. To date, knockdown of PinX1 was found to substantially increased the radiotherapy effect of esophageal squamous cell carcinomas (ESCC) [13]. These results prompted us to investigate the role PinX1 in OS radioresistance.

\section{Materials and methods}

Cell lines. A telomerase-positive OS cell line Saos-2 and a telomerase-negative OS cell line $\mathrm{U} 2 \mathrm{OS}$ were purchased from 
the Cell Bank of the Chinese Academy of Science, Shanghai, China. The cells were cultured in RPMI-1640 medium (Hyclone) supplemented with $10 \%$ fetal bovine serum and antibiotics (100 U/ml penicillin and $100 \mu \mathrm{g} / \mathrm{ml}$ streptomycin) at $5 \% \mathrm{CO}_{2}, 37^{\circ} \mathrm{C}$, and $95 \%$ humidity.

Construction of the recombinant lentiviral vector and transfection. The construction of the PinX1 shRNA lentiviral expression vector has been previously determined [14]. Saos-2 or U2OS cells were incubated in medium without serum and antibiotics for $24 \mathrm{~h}$. After mixed gently according to the manufacturer's instructions and incubated for $20 \mathrm{~min}$ at room temperature, the transfection mixture of siRNA and Lipofectamine 2000 (Invitrogen) was added into culture plates. After $6 \mathrm{~h}$, the transfection mixture was replaced by medium. Cells were harvested at $48 \mathrm{~h}$ after transfection.

Real-time quantitative PCR (qPCR). Total RNA was isolated using TRIzol reagent (Invitrogen). Reverse transcription reaction was performed using $2 \mu \mathrm{g}$ of total RNA with a first strand cDNA kit (Takara). PCR amplification was performed for $20 \mathrm{~s}$ at $95^{\circ} \mathrm{C}$, followed by 40 cycles at $95^{\circ} \mathrm{C}$ for $5 \mathrm{~s}$, and annealing/extension at $60^{\circ} \mathrm{C}$ for $30 \mathrm{~s}$ in ABI 7300 Thermocycler (Applied Biosystems), using the SYBR Premix Ex Taq kit (Takara). The PinX1 sense primer was 5'-ATGTCTATGCTGGCTGAA-3', and the antisense primer was 5'-TCTGTGGCTCCTTGCT-3'. For the GAPDH gene, the sense primer was 5' - CCCACATGGCCTCCAAGGAGTA -3', and the antisense primer was 5'- GTGTACATGGCAACTGTGAGGAGG -3'. Data analysis was done using the $2^{-\Delta \Delta C T}$ method for relative quantification, and all samples were normalized to GAPDH.
Genomic DNA was extracted from cells by standard procedures using QIAamp DNA Mini Kit (Qiagen, Hilden, Germany). Relative telomere length (RTL) was detected by using qPCR described by Cawthon previously [15].

Western blotting. Cell lysates were made with standard methods, then $20 \mu \mathrm{g}$ of protein samples were separated by $5 \%$ SDS-PAGE, and transferred to polyvinylidene fluoride (PVDF). After blocked with a buffer containing 5\% low fat milk and $0.1 \%$ Tween-20 in Tris-buffered saline (TBST), the PVDF membrane was incubated with a mouse anti-human PinX1 polyclonal antibody (Abnova, Taipei City, Taiwan) and second antibody. Finally, results were photographed with ECL substrate.

Flow cytometric analysis. Cells were harvested directly or $48 \mathrm{~h}$ after transfection and washed with ice-cold phosphate-buffered saline (PBS). The PI/RNase staining kits (Multisciences Biotech, Hangzhou, China) and annexin Vfluorescein isothiocyanate (FITC) apoptosis detection kits (KeyGEN Biotech, Nanjing, China) were used to detect cell cycle and apoptosis in a FACScan instrument (Becton Dickinson), respectively.

Colony formation assay. The cells were plated into 6-well plates at various densities $(100,200,400,600,1000,1500,3000$ cells/well) with $2 \mathrm{~mL}$ culture medium. The next day, cells were irradiated with graded doses $(0,1,2,4,6,8,10 \mathrm{~Gy})$, respectively, followed by immediate incubation at $37^{\circ} \mathrm{C}, 5 \% \mathrm{CO}_{2}$ for 14 days. The clones when greater than 50 cells were counted under microscope. The cloning efficiency $(\%)=($ the number of clones / the number of seed cells) $\times 100 \%$. The data were fit into the single-hit multi-target model and survival curve
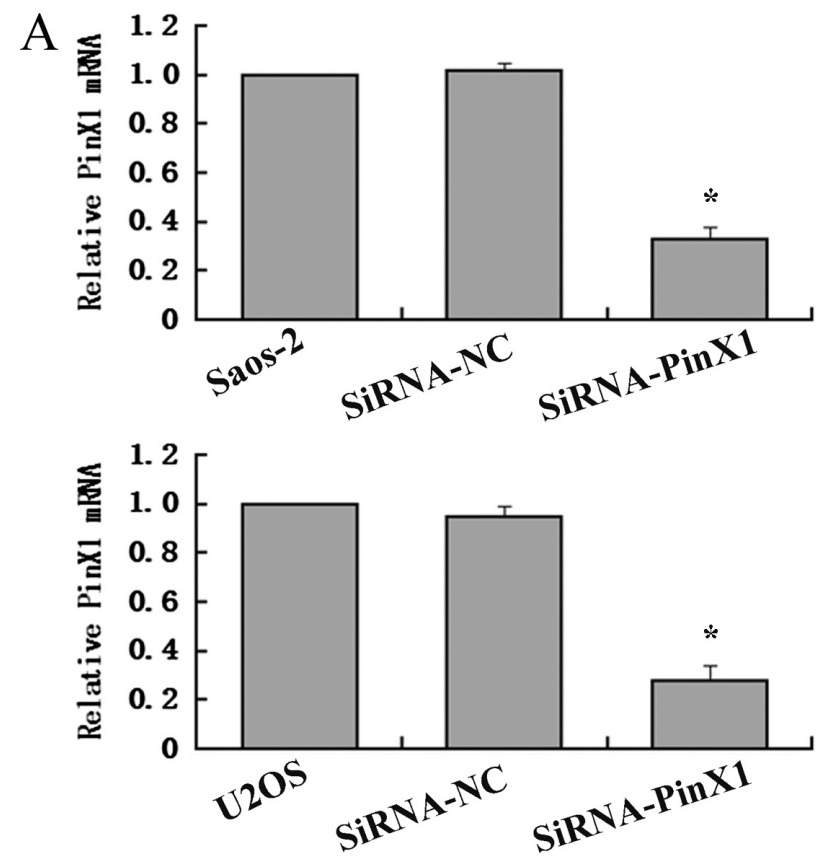

B
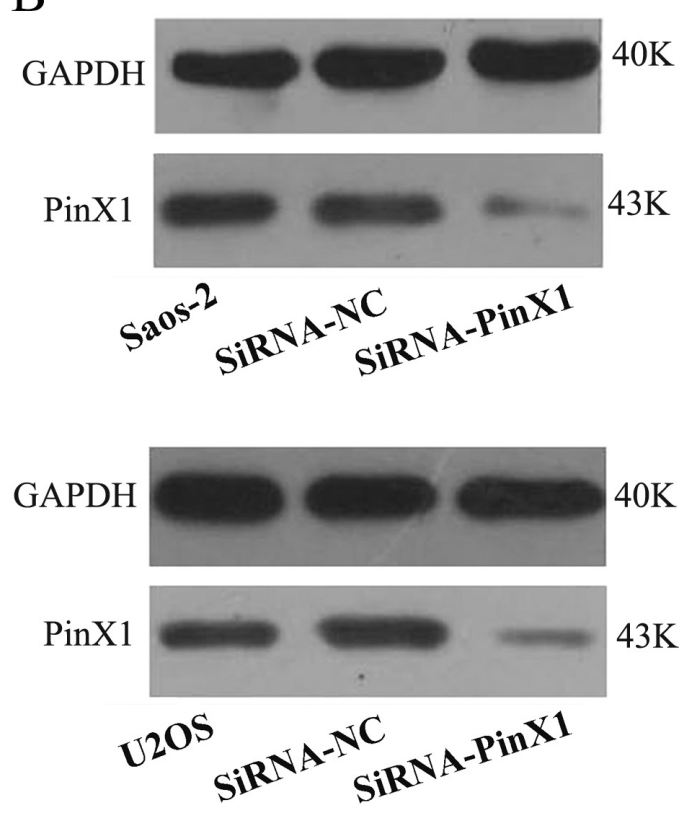

Figure 1. Effect of PinX1 RNAi on the mRNA and protein expression levels in OS cell lines. (A) mRNA expression levels of PinX1 were detected by qPCR. (B) PinX1 protein expression levels in PinX1 siRNA-infected and control cells were detected by Western blotting. ${ }^{\star} P<0.05$. 
of each group were demonstrated by formula $y=1-(1-\exp (-$ $\left.\left.\mathrm{k}^{\star} \mathrm{x}\right)\right)^{\wedge} \mathrm{N}$ using Graphpad prism 5.0 software. The cell-survival curve used the irradiation dosage as the abscissa axis and the survival fraction (SF) as the vertical axis, cells' constant $(\mathrm{k})$ and extrapolation number $(\mathrm{N})$ values were calculated according to the curve. The average lethal dosage of cells (D0) and the quasi-field dosage $(\mathrm{Dq})$, which indicates the repair ability of cells to sublethal injury, were calculated as follows: $\mathrm{D}_{0}=1 / \mathrm{k}$, $\mathrm{Dq}=(\mathrm{N}-1) / \mathrm{k}$.

Statistical analysis. Results for continuous variables were expressed as mean $\pm \mathrm{SD}$. Differences were assessed using Student's t-test. A value of $P<0.05$ was considered statistically significant. All analyses were performed using SPSS 16.0 software (SPSS Inc., Chicago, IL, USA).

\section{Results}

PinX1 expression was suppressed by RNA interference (RNAi). To verify the inhibition efficiency of PinX1 in Saos-2 and U2OS cells, PinX1 expression was detected by qPCR and Western blotting. Expression of PinX1 mRNA (Figure 1A)

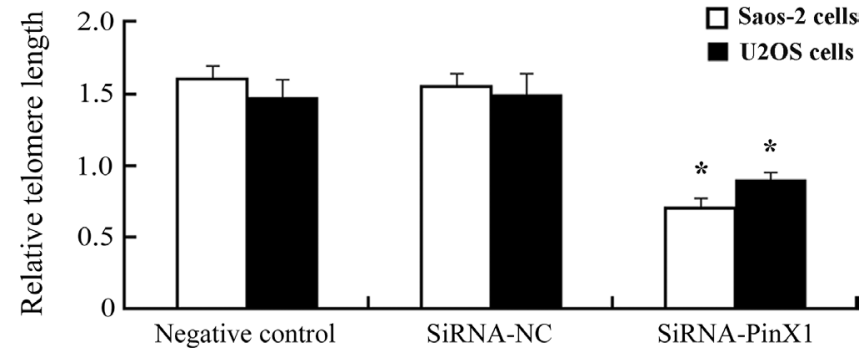

Figure 2. Detection of relative telomere length. PinX1 knockdown shortened telomere length in Saos-2 and U2OS cells, as compared with the mock-transfected and control groups. ${ }^{\star} P<0.05$.

and PinX1 protein (Figure 1B) in RNAi group were both significantly decreased in the two cell lines, as compared with negative control or mock vector group.

Relative telomere length in OS cell lines was detected by qPCR. As shown in Figure 2, RTLs of negative control, mock vector and RNAi group were $1.60 \pm 0.10,1.55 \pm 0.09$ and 0.71 \pm 0.08 , respectively, in Saos-2 cells, while the results were 1.48
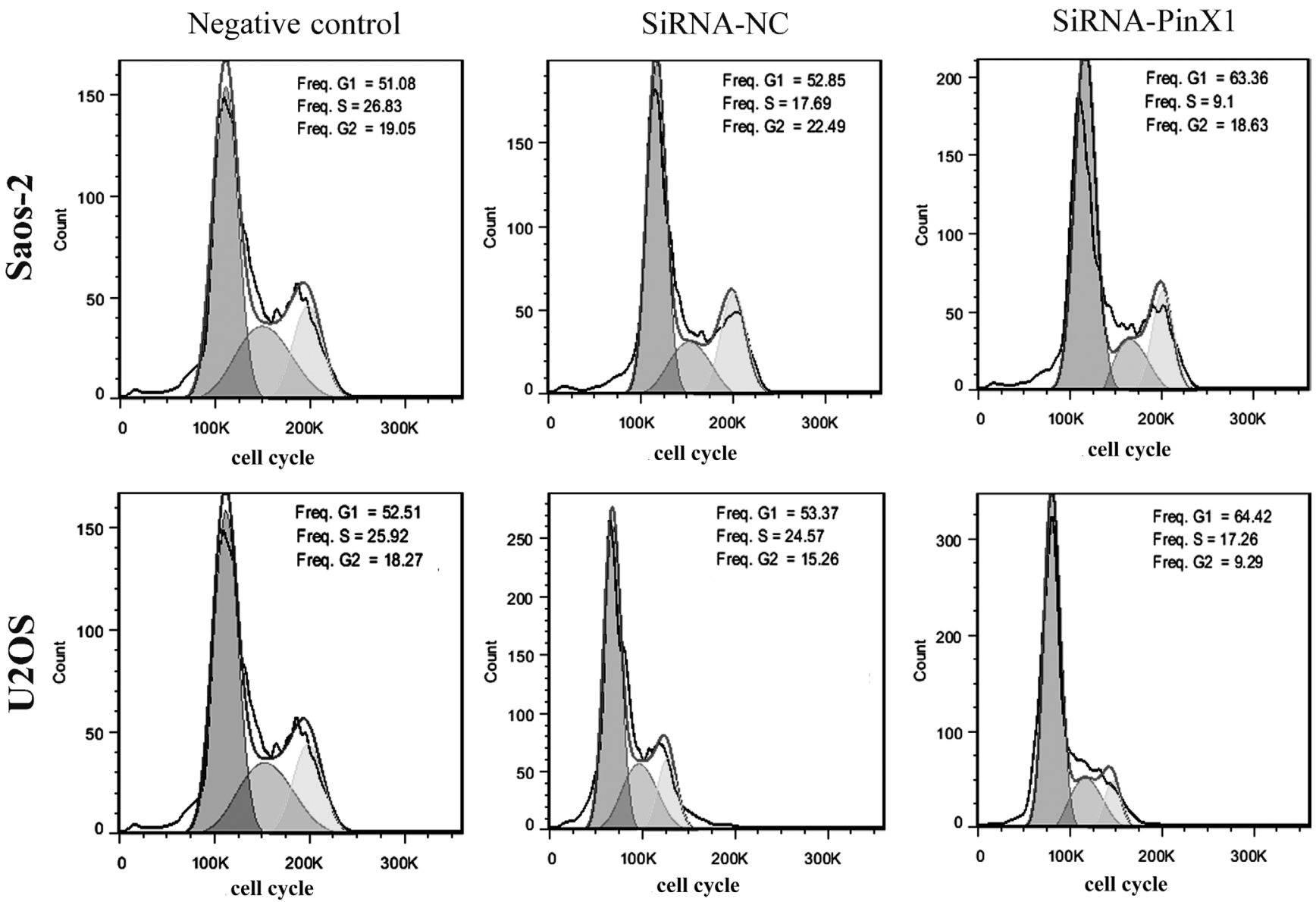

Figure 3. Flow cytometry assay of cell cycle. PinX1 down-regulation resulted in cell arrest in $\mathrm{G}_{1}$ phase of cell cycle and a slight decrease of $S$ phase or $\mathrm{G}_{2}$ phase in Saos-2 and U2OS cells, as compared with the mock-transfected and control groups. 
Table 1. Effects of PinX knockdown on OS cells survival after irradiation

\begin{tabular}{lcccccccc}
\hline & \multicolumn{9}{c}{ Saos-2 } & \multicolumn{3}{c}{ U2OS } \\
\cline { 2 - 9 } Group & $\mathrm{SF} 2$ & $\mathrm{D}_{0}(\mathrm{~Gy})$ & $\mathrm{D}_{\mathrm{q}}(\mathrm{Gy})$ & $\mathrm{SER}_{\mathrm{SF} 2}$ & $\mathrm{SF} 2$ & $\mathrm{D}_{0}(\mathrm{~Gy})$ & $\mathrm{D}_{\mathrm{q}}(\mathrm{Gy})$ & $\mathrm{SER}_{\mathrm{SF} 2}$ \\
\hline Control & $0.842 \pm 0.012$ & 2.83 & 5.97 & - & $0.776 \pm 0.015$ & 3.03 & 3.42 & - \\
SiRNA-NC & $0.838 \pm 0.015$ & 2.76 & 5.57 & 1.004 & $0.760 \pm 0.021$ & 2.95 & 3.11 & 1.021 \\
SiRNA-PinX1 & $0.631 \pm 0.018^{*}$ & 2.47 & $1.86^{*}$ & 1.334 & $0.545 \pm 0.016^{*}$ & $2.18^{*}$ & $1.34^{*}$ & 1.424 \\
\hline
\end{tabular}

$\mathrm{SF} 2$, surviving fraction of $2 \mathrm{~Gy} ; \mathrm{D}_{0}$, mean lethal dose; $\mathrm{D}_{\mathrm{q}}$, quasithreshold dose; SER, sensitization enhancement ratio.

${ }^{*} P<0.05$

$\pm 0.12,1.51 \pm 0.14$ and $0.89 \pm 0.06$ in U2OS cells. RTL was much shorter in SiRNA-PinX1 group of both cell lines. These data indicated that down-regulation of PinX1 expression could shorten telomere length in Saos-2 and U2OS cells.

Effects on cell cycle and apoptosis. Flow cytometry assay was performed to analyze the effects of PinX1 knockdown on cell cycle and apoptosis of OS cells. As shown in Figure 3, decreased expression of PinX1 resulted in cell arrest in $G_{1}$ phase of cell cycle and a slight decrease of $S$ phase or $G_{2}$ phase in Saos-2 and U2OS cells, as compared with the mock vector and control groups $(P<0.05)$. Meanwhile, suppression of PinX1 induced a dramatic increase of apoptosis in the two cell lines, as cells' proportion in up right (UR) quadrant (late apoptosis cells) and low right (LR) quadrant (early apoptosis cells) was increased $(P<0.05$, Figure 4$)$.

Knockdown of PinX1 resulted in increased radiosensitivity. To study whether PinX1 affected radiosensitivity, cell survival was evaluated by clonogenic assay following $0 \sim 10 \mathrm{~Gy}$
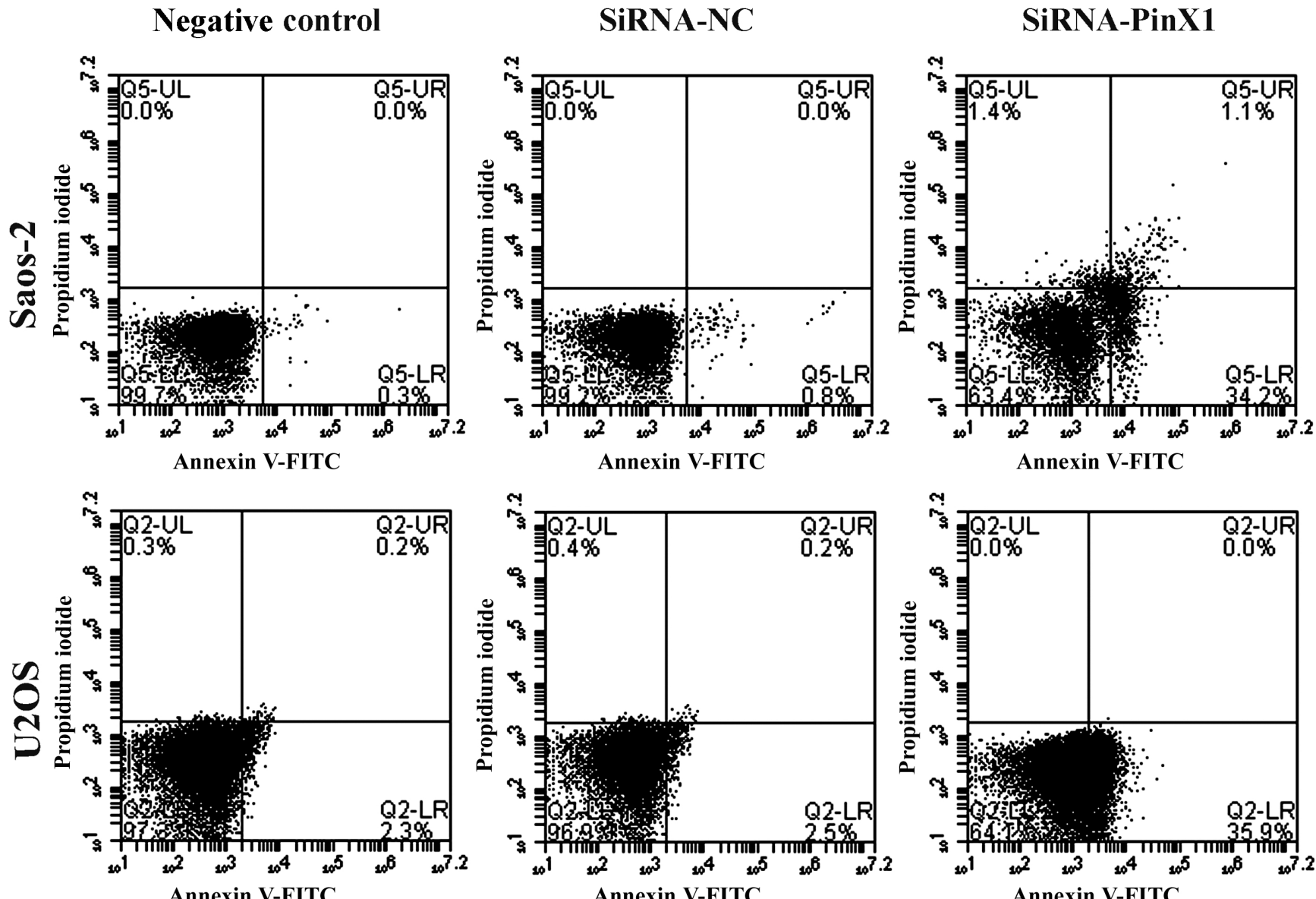

Figure 4. Flow cytometry assay of apoptosis. SiRNA-PinX transfected groups showed a dramatic increase of apoptosis, as compared with the mocktransfected and control groups. Up left (UL), Necrosis cells; Low left (LL), Normal cells; Up right (UR) Late apoptosis cells; Low right (LR), Early apoptosis cells. 

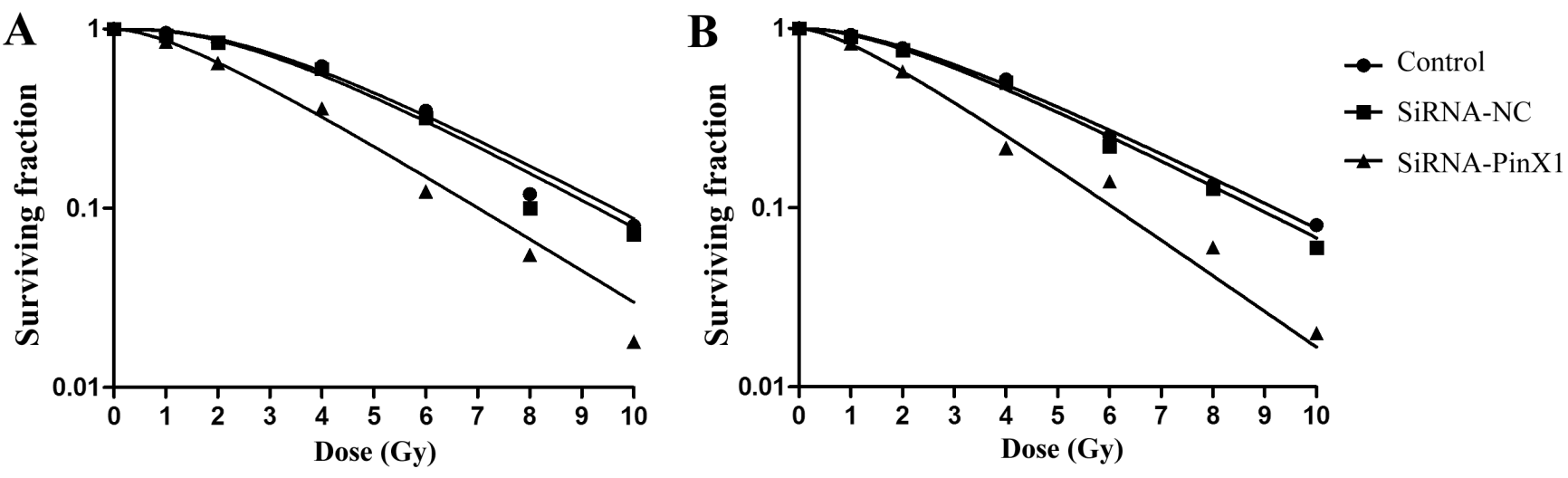

Figure 5. Effects of PinX knocdown on OS cells survival after irradiation. The cells in different groups were irradiation with graded doses (0, 1, 2, 4, 6, $8,10 \mathrm{~Gy}$ ), respectively. Cell survival was determined using colony formation assay and then survival curves of each group were analyzed according to Graphpad prism 5.0 software. (A) Saos-2 cell line. (B) U2OS cell line.

radiation. As shown in Table 1 and Figure 4, PinX1 knockdown significantly decreased the value of SF2 (surviving fraction of 2 Gy) and $\mathrm{D}_{\mathrm{q}}$ both in Saos- 2 and U2OS cells, and decreased the $\mathrm{D}_{0}$ value in $\mathrm{U} 2 \mathrm{OS}$ cells $(P<0.05)$. The sensitization enhancement ratio $\left(\mathrm{SER}_{\mathrm{SF} 2}\right)$ in Saos-2 and U2OS cells was 1.33 and 1.42, respectively. These data showed that suppression of PinX1 increased the radiosensitivity of OS cells, regardless of telomerase status.

\section{Disscussion}

Telomere/telomerase interplay is an important mechanism involved in the maintenance of genetic chromosome stability and its dysfunction has emerged as having a causative role in carcinogenesis [16]. Telomeres provide genomic stability by protecting chromosome ends. However, for several reasons, telomeres shorten with each round of DNA replication and can eventually become uncapped by this attrition, leading to their recognition as DNA breaks and thus to permanent cell-cycle arrest or apoptosis [17]. Maintenance of telomere length by telomerase is critical to preserving the replicative potential of cancer cells [19]. In addition to telomerase, a large number of factors help maintain telomere integrity. In mammals, chief among these are the members of the shelterin complex, including the duplex telomere repeat binding proteins TRF1 and TRF2 [19]. Shelterin proteins recruit a host of other factors to the telomere including PinX1 [20]. TRF1 binds PinX1, which directly interacts with and inhibits telomerase action [21].

PinX1, an evolutionary conserved nuclear protein, was originally identified as an intrinsic telomerase inhibitor and a putative tumor suppressor because of its binding to, and inhibition of, telomerase. Other functions of PinX1 include human telomerase reverse transcriptase nucleolar localization and being involved in faithful mitotic chromosome segregation [22,23]. PinX1 is downregulated in most human malignancies and cancer cell lines examined, and PinX1 levels were inversely correlated with tumor multiplicity, advanced $\mathrm{N}$ classification, high proliferation index, and poor survival [24]. Also, functional analysis showed that transfection with PinX1 induced apoptosis, $G_{1}$ arrest, and cellular senescence in colorectal cancer cells [10], whereas knockdown of PinX1 dramatically enhanced paclitaxel cytotoxicity in cervical squamous cell carcinomas [25]. Recently, Qian et al [13] found that, knockdown of PinX1 substantially increased ESCC cells' therapeutic efficacy of radiation both in vitro and in vivo, while ectopic overexpression of PinX1 decreased ESCC cells' radiosensitivity. Furthermore, PinX1 resistance to radiotherapy was attributed to PinX1 maintaining telomere stability. Consistent with these studies, we found PinX1 deletion resulted in telomere shortening, increased apoptosis, $G_{1}$ phase arrest and radiation sensitivity enhancement both in telomerase-positive OS cell line Saos-2 and telomerase-negative OS cell line U2OS, suggesting that PinX1 could serve as a novel predictor for radiotherapy response to OS patients, and the pathway of PinX1-mediated telomere stability might represent a new target to improve the radiotherapy effect of OS.

Many and varied mechanisms of resistance to IR treatment are proposed. Among them, an inverse relationship between telomere length (TL) and radiosensitivity has been recently advanced [26]. Late passage normal human fibroblasts with short telomeres are more sensitive to IR than their younger counterparts with longer telomeres [27]. Even individuals with short telomeres have been shown to have higher frequencies of IR-induced micronuclei, a commonly used marker of cell damage and DNA double-strand break (DSB), than individuals with longer telomeres [28].

Moreover, radiosensitivity is fairly well correlated with inhibition of telomerase activity in human cancer cells. The ability of telomerase confer radioresistance may depend on its ability to preferentially elongate short, near-dysfunctional telomeres and protect cells from IR-induced apoptosis and necrosis [29]. In the present study, knockdown of PinX1 enhances tumor radiosensitivity and shorten TL regardless 
of telomerase status, which indicated that PinX1 resulted in telomere dysfunction in telomerase-independent mechanisms. Previous study have shown that, the enhanced radiosensitivity observed in telomerase-deficient cells with short telomeres may be due to chromosome fusions that occur between the short telomeres and the radiation-induced DSBs, which interfere with the proper repair of the DSB, leading to the formation of chromosomal rearrangements [30,31].

Radiosensitivity may also be closely linked with impairment of DNA damage response (DDR) processes. Telomere shortening may cause increased radiosensitivity by altering the kinetics of repair due to changes in chromatid structure that limits the access of DDR proteins [32]. However, the relationships between IR, radiosensitivity, TL, telomerase activity, and DDR, and the role of PinX1 still remain inconclusive.

In conclusion, we demonstrate that suppression of PinX1 resulted in telomere shortening and enhanced radiosensitivity in OS cell lines, regardless of telomerase status. The specific mechanisms need further study.

\section{References}

[1] OTTAVIANI G, JAFFE N. The epidemiology of osteosarcoma. Cancer Treat Res 2009; 152: 3-13. http://dx.doi. org/10.1007/978-1-4419-0284-9 1

[2] ANDO K, HEYMANN MF, STRESING V, MORI K, REDINI F, et al. Current therapeutic strategies and novel approaches in osteosarcoma. Cancers (Basel) 2013; 5: 591-616. http:// dx.doi.org/10.3390/cancers5020591

[3] LI HX, MENG QP, LIU W, LI YG, ZHANG HM, et al. IMPDH2 mediate radioresistance and chemoresistance in osteosarcoma cells. Eur Rev Med Pharmacol Sci 2014; 18: 3038-3044.

[4] QIANG W, WU Q, ZHOU F, XIE C, WU C, et al. Suppression of telomere-binding protein TPP1 resulted in telomere dysfunction and enhanced radiation sensitivity in telomerase-negative osteosarcoma cell line. Biochem Biophys Res Commun 2014; 445: 363-368. http://dx.doi.org/10.1016/j. bbrc.2014.02.001

[5] CASTELla M, PUERTO S, CREUS A, MARCOS R, SURRALLES J. Telomere length modulates human radiation sensitivity in vitro. Toxicol Lett 2007; 172: 29-36. http://dx.doi. org/10.1016/j.toxlet.2007.05.012

[6] WONG KK, CHANGS, WEILER SR, GANESAN S, CHAUDHURI J, et al. Telomere dysfunction impairs DNA repair and enhances sensitivity to ionizing radiation. Nat Genet 2000; 26: 85-88. http://dx.doi.org/10.1038/79232

[7] ZHOU XZ. PinX1: a sought-after major tumor suppressor at human chromosome 8p23. Oncotarget 2011; 2: 810-819.

[8] ZHOU XZ, LU KP. The Pin2/TRF1-interacting protein PinX1 is a potent telomerase inhibitor. Cell 2001; 107: 347-359. http://dx.doi.org/10.1016/S0092-8674(01)00538-4

[9] LAI XF, SHEN CX, WEN Z, QIAN YH, YU CS, et al. PinX1 regulation of telomerase activity and apoptosis in nasopharyngeal carcinoma cells. J Exp Clin Cancer Res 2012; 31: 12. http://dx.doi.org/10.1186/1756-9966-31-12
[10] ZHANG R, ZHAO J, WANG X, WANG LL, XU J, et al. PinX1 without the G-patch motif suppresses proliferation, induces senescence, but does not inhibit telomerase activity in colorectal cancer SW480 cells. Oncol Rep 2014; 32: 286-292. http:// dx.doi.org/10.3892/or.2014.3199

[11] CAI MY, ZHANG B, HE WP, YANG GF, RAO HL, et al. Decreased expression of PinX1 protein is correlated with tumor development and is a new independent poor prognostic factor in ovarian carcinoma. Cancer Sci 2010; 101: 1543-1549. http://dx.doi.org/10.1111/j.1349-7006 $.2010 .01560 . \mathrm{x}$

[12] HAWKINS GA, CHANG BL, ZHENG SL, ISAACS SD, WILEY KE, et al. Mutational analysis of PINX1 in hereditary prostate cancer. Prostate 2004; 60: 298-302. http://dx.doi. org/10.1002/pros.20075

[13] QIAN D, ZHANG B, HE LR, CAI MY, MAI SJ, et al. The telomere/telomerase binding factor PinX1 is a new target to improve the radiotherapy effect of oesophageal squamous cell carcinomas. J Pathol 2013; 229: 765-774. http://dx.doi. org/10.1002/path.4163

[14] ZHANG B, BAI YX, MA HH, FENG F, JIN R, et al. Silencing PinX1 compromises telomere length maintenance as well as tumorigenicity in telomerase-positive human cancer cells. Cancer Res 2009; 69: 75-83. http://dx.doi.org/10.1158/00085472.CAN-08-1393

[15] CAWTHON RM. Telomere measurement by quantitative PCR. Nucleic Acids Res 2002; 30: e47. http://dx.doi. org/10.1093/nar/30.10.e47

[16] ARTANDI SE, DEPINHO RA. Telomeres and telomerase in cancer. Carcinogenesis 2010;31:9-18. http://dx.doi. org/10.1093/carcin/bgp268

[17] SPROUSE AA, STEDING CE, HERBERT BS. Pharmaceutical regulation of telomerase and its clinical potential. J Cell Mol Med 2012; 16: 1-7. http://dx.doi.org/10.1111/j.1582-4934 .2011.01460.x

[18] FELDSER DM, GREIDER CW. Short telomeres limit tumor progression in vivo by inducing senescence. Cancer Cell 2007; 11: 461-469. http://dx.doi.org/10.1016/j.ccr.2007.02.026

[19] DE LANGE T. Shelterin: the protein complex that shapes and safeguards human telomeres. Genes Dev 2005; 19: 2100-2110. http://dx.doi.org/10.1101/gad.1346005

[20] LEE TH, TUN-KYI A, SHI R, LIM J, SOOHOO C, et al. Essential role of Pin1 in the regulation of TRF1 stability and telomere maintenance. Nat Cell Biol 2009; 11: 97-105. http:// dx.doi.org/10.1038/ncb1818

[21] BANIK SS, COUNTER CM. Characterization of interactions between PinX1 and human telomerase subunits hTERT and hTR. J Biol Chem 2004; 279: 51745-51748. http://dx.doi. org/10.1074/jbc.M408131200

[22] LIN J, JIN R, ZHANG B, YANG PX, CHEN H, et al. Characterization of a novel effect of hPinX1 on hTERT nucleolar localization. Biochem Biophys Res Commun 2007; 353: 946952. http://dx.doi.org/10.1016/j.bbrc.2006.12.123

[23] YUAN K, LI N, JIANG K, ZHU T, HUO Y, et al. PinX1 is a novel microtubule-binding protein essential for accurate chromosome segregation. J Biol Chem 2009; 284: 23072-23082. http://dx.doi.org/10.1074/jbc.M109.001990 
[24] LIU JY1, QIAN D, HE LR, LI YH, LIAO YJ, et al. PinX1 suppresses bladder urothelial carcinoma cell proliferation via the inhibition of telomerase activity and p16/cyclin D1 pathway. Mol Cancer 2013; 12: 148. http://dx.doi.org/10.1186/14764598-12-148

[25] TIAN XP, QIAN D, HE LR, HUANG H, MAI SJ, et al. The telomere/telomerase binding factor PinX1 regulates paclitaxel sensitivity depending on spindle assembly checkpoint in human cervical squamous cell carcinomas. Cancer Lett 2014; 353: 104-114. http://dx.doi.org/10.1016/j. canlet.2014.07.012

[26] ZHONG YH, LIAO ZK, ZHOU FX, XIE CH, XIAO CY, et al. Telomere length inversely correlates with radiosensitivity in human carcinoma cells with the same tissue background. Biochem Biophys Res Commun 2008; 367: 84-89. http:// dx.doi.org/10.1016/j.bbrc.2007.12.078

[27] RUBIO MA, KIM SH, CAMPISI J. Reversible manipulation of telomerase expression and telomere length. Implications for the ionizing radiation response and replicative senescence of human cells. J Biol Chem 2002; 277: 28609-28617. http:// dx.doi.org/10.1074/jbc.M203747200
[28] CASTELLA M, PUERTO S, CREUS A, MARCOS R, SURRALLES J. Telomere length modulates human radiation sensitivity in vitro. Toxicol Lett 2007; 172: 29-36. http://dx.doi. org/10.1016/j.toxlet.2007.05.012

[29] RUBIO MA, DAVALOS AR, CAMPISI J. Telomere length mediates the effects of telomerase on the cellular response to genotoxic stress. Exp Cell Res 2004; 298: 17-27. http://dx.doi. org/10.1016/j.yexcr.2004.04.004

[30] LATRE L, TUSELL L, MARTIN M, MIRO R, EGOZCUE J, et al. Shortened telomeres join to DNA breaks interfering with their correct repair. Exp Cell Res 2003; 287: 282-288. http:// dx.doi.org/10.1016/S0014-4827(03)00134-4

[31] SOLER D, PAMPALONA J, TUSELl L, GENESCA A. Radiation sensitivity increases with proliferation-associated telomere dysfunction in nontransformed human epithelial cells. Aging Cell 2009; 8: 414-425. http://dx.doi.org/10.1111/ j.1474-9726.2009.00488.x

[32] MLADENOV E, MAGIN S, SONI A, ILIAKIS G. DNA doublestrand break repair as determinant of cellular radiosensitivity to killing and target in radiation therapy. Front Oncol 2013; 3: 113. http://dx.doi.org/10.3389/fonc.2013.00113 